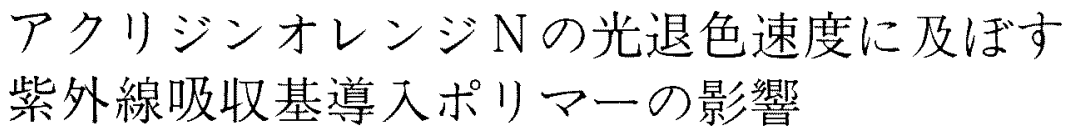

$\begin{array}{ll}\text { 群馬大学工学部 } & \text { 鈴木洋正 ・石井美治 } \\ \text { 名古浜大学工学部 } & \text { 山下雄也 }\end{array}$

\title{
THE EFFECT OF POLYMERS HAVING ULTRAVIOLET ABSORPTIVE GROUPS ON PHOTOFADING RATE OF ACRIDINE ORANGE N
}

\author{
By Hiromasa Suzuki ${ }^{* 1}$, Yoshiji Ishii ${ }^{* 1}$ and Yuya Yamashita ${ }^{* 2}$ \\ *1 (Department of Polymer Chemistry, Faculty of Engineering, \\ Gunma University, Kiryu 376, Japan) \\ -2 (Department of Synthetic Chemistry, Faculty of Engineering, \\ Nagoya University, Furo-cho, Chikusa-ku, Nagoya 464, Japan)
}

The photofading of Acridine Orange $\mathrm{N}$ in a dioxane-ethanol mixture has studied in the presence of polymers having ultraviolet absorptive groups. The results were compared with the measurements made in the presence of the coresponding ultraviolet absorptive molecules. The polymers used were: CMPT prepared by the reaction of $32.4 \%$ chloromethylated polystyrene (CMPSt), with $2-\left(2^{\prime}, 4^{\prime}\right.$ dihydroxyphenyl)benzotriazole, and CMPB prepared by the reaction of CMPSt with 2,4-dihydroxybenzophenone. CMPT contained 4.5\% 2-(2'-hydroxyphenyl)benzotriazole (HBT) unit and $27.9 \%$ chloromethylstyrene (CMSt) unit and the rest $67.6 \%$ styrene $(\mathrm{St})$ unit. CMPB contained $5.1 \%$ 2-hydroxybenzophenone (HBP) unit, 27.3\% CMSt and the rest \% St unit. The corresponding molecules used were 2-(2'-hydroxy-4'-methoxyphenyl)benzotriazol (HMBT) and 2-hydroxy-4methoxybenzophenone (HMBP).

In the case of irradiation with light of overall wavelengths under Xenon-arc lamp, CMPT and CMPB did not act as retarder for the photofading of Acridine Orange $\mathrm{N}$ in the solution, CMSt unit in these polymers underwent photochemical solvolysis in the solution to afford free $\mathrm{HCl}$, which showed an accelerating action on the photofading rate of the dye. On the other hand, in the case of irradiation with light above $290 \mathrm{~nm}$, to which CMSt is insensitive, the effects of CMPT and CMPB were similar to HMBT and HMBP; these worked as retarder on the photofading in the order: $\mathrm{CMPT}>\mathrm{HMBT}>\mathrm{CMPB}>\mathrm{HMBP}$.

HBT and HBP groups acted as both quencher and screener. The quenching effect was dominant under the low concentration of these additives, and the screening effect predominated under the high concentration of the additives.

(Received April 13, 1985)

\section{1. 緒言}

先に著者らは，紫外線吸収基含有ポリマーの染料光退 色に及㳆す影響について検討し，ポリマー側銷に導入し た紫外線吸収剤ユニット(2-ヒドロキシベンゾフェノン 構造)が染料光退色抑制に有效であること ${ }^{1,2)}$ ，また，ポ
リマー主鎖としてはメタクリル酸メチルユニットよりむ スチレン $(\mathrm{St})$-ニットの方が光退色抑制に有利である こと扣よび市販の紫外線吸収剤である2ーヒドロキシー4メトキシベンゾフェノン (HMBP) よりあ紫外線吸収基 含有ポリマーの示す優れた光退色抑制効果のいくつ汃の 要因をポリマー効果と総称して説明した2。 
今までに使用した紫外線吸取基含有ポリマーは，す心゙ て2ーヒドロキシベンゾフュノン(HBP) 锖造多プのも のであり，徉って，本武では，典型的な紫外線吸收成の 6う1つ0夕イプ0 2-(2'-ヒドロキシフェール)ベン ゾトリアゾール (HBT) 楧造をポリマ一鎖に筫入し，乙 のタイプの紫外線吸収基含有ポリマーの染料光退色に及 ぼす効果について検討した，HBT 情造は，クロロメチ ル化ポリスチレン(CMPSt)に2-(2'，4'ージヒドロキシ フェニル)ベンゾトリアゾール (DHBT) 在反応させるこ しにより算入した。また，同様に2，4ージヒドロキシべ ンゾフェノン (DHBP)を反応させることにより HBP 構 造屯犋入可能ですった。しれらタイプの異なる2㮔の柴 外線吸取基含有ポリマーの染料光退色に及はすす效果の優

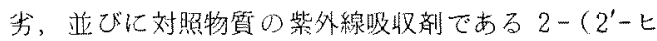
ドロキシー4'-メトキシフェニル)ベンゾトリアゾール (HMBT) 拈じHMBPの効果についても合执て比校 検討した。染料としては，全般に耐光性の上くない塩基

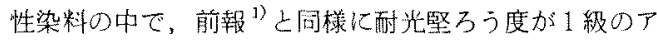
クリジンオレンジNを選で染料モデルとして使用した。

\section{2. 実験}

\section{1 試薬および染料}

St 㧍よびDHBP：前報 ${ }^{1)}$ 上同様に精整して使用した。 HMBP：市販 1 級品在メ夕ノールより 2 回再結鼠し て用いた。 m. p. $65.5 \sim 66.0^{\circ} \mathrm{C}\left(66.0^{\circ} \mathrm{C}^{3)}\right)$ 。

DHBT：o-ートロアニリンとレゾルシンとから2'， 4'-ジヒドロキシー2-ニトロアゾベンゼンを合成し，てれ を亜鉛末で還元する方法により合成した 。粗生成物を エ夕ノ一ル一水の混合溶媒加ら4回再結晶至毕ない，淡 黄土色つ針状結晶を得た。 m. p. 200.8 $201.7^{\circ} \mathrm{C}$ ( 200.5 $\left.\sim 201.5^{\circ} \mathrm{C}^{9}\right)$ 。元素分析值: C $63.86 \%, \mathrm{H} 4.10 \%$ ， N 18.86\%(計算值：C $63.43 \%, H 3.99 \%, N 18.49 \%$ )。

HMBT：DHBTのジメチル硫酸によるメトキシ化に よって合成しだ。エタノールより2回丽結晶老行ない, 淡黄色の針状緒晶䘮得た。 m. p. $128.0 \sim 129.5^{\circ} \mathrm{C}(128.5$ $\left.\sim 130.0^{\circ} \mathrm{C}^{1}\right)$ 。元素分析值：C $64.91 \% ， \mathrm{H} 4.55 \% ， \mathrm{~N}$ 17.58\% (計算值：C 64.72\%，H 4.59\%，N 17.42\%)。 ポりスチレン (PSt)：St の瑟濁重合に上り合成し $た^{5)}$.

CMPSt：メチルクロロメチルエーテルを溶媒萧試剂

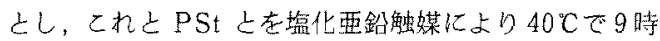
間反応させだ)。反応液を大過剩のメタノールに注ぎ込 み、ポリマーを戦離した。これをジオキサンに溶解し, 大過剩のメタノールに注ぎ，再沈殿させた。この操作を再 度行ない，沈期物老沪過した缕，恒量になるまで室温で 真空乾祝を行なってCMPStを得た。CMPStのNMR
スペクトルより求めたクロロメチル化率は $32.4 \mathrm{~mol} \%$ $\left(2.71 \times 10^{-3} \mathrm{~mol} / \mathrm{g}\right)$ であった。

溶 媒：常法に上り精製して用いた。

染 料：アクリジンオレンジN(C. I. Basic Orange 14)は市販 1 級品をメタノールより3回再結晶して用い to

\section{2 紫外線吸收基含有ポリマ一の合成}

CMPSt $2.00 \mathrm{~g}\left(-\mathrm{CH}_{2} \mathrm{Cl}\right.$ 基量 $\left.5.4 \times 10^{-3} \mathrm{~mol}\right)$ \& DHBT $1.34 \mathrm{~g}\left(5.9 \times 10^{-3} \mathrm{~mol}\right)$ アセトン $20 \mathrm{ml}$ 中に溶 加し，炭酸力りウム $1.05 \mathrm{~g}\left(7.6 \times 10^{-3} \mathrm{~mol}\right)$ 在加元，港 拌しながら還流下で5时間反应行なった。冷却後，ア セトン $50 \mathrm{ml}$ を反応液に加え, 盾翻した後, 沪過した。 沪液を大副剩のメタノール中に注ぎ，ポリマーを睹離し た。とのポリマーを $40 \mathrm{ml}$ のオオキサンに溶かし，大過 剩のメタノール中に注ぎ，再沈殿させた。再びポリマー をジオキサンに溶加し，酸性にした大過剩の水上り再沈 殿させた。更に中性下て 2 回再沈骐させた後, 十分に水 珗し，最後にメタノールで十分に珗浄した。恒量に達す るまで室潹で真空乾燥在行っって，2.10gのポリマーを 得た。このポリマーをCMPTと略記する。

また，CMPSt しDHBPとを同㥞に反応させ，単離， 精製してポりマーを得た。このポリマーを CMPB と呼

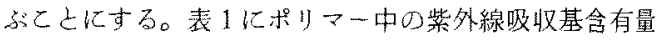
および礐換率走した。おお，この合成条件下では，べ ンジルアルコール型 (Poly - $\left.\mathrm{O}-\mathrm{CH}_{2} \mathrm{OH}\right)$ あるいは架 橋型 (Poly- O $-\mathrm{CH}_{2} \mathrm{OCH}_{2}-(\mathrm{O}-\mathrm{Poly})$ は生じない 屯心よ考无る ${ }^{6)}$ 。<smiles>CCCc1ccccc1CCC(CCC)c1ccc(CCl)cc1</smiles><smiles>COc1ccc(C(=O)c2ccc(C(=O)O)cc2O)c(O)c1</smiles>

Table 1 Polymer compositions.

\begin{tabular}{|c|c|c|c|}
\hline \multirow{2}{*}{ Polymer } & \multicolumn{2}{|c|}{$\begin{array}{c}\text { Functional group } \\
\text { (mol o\%) }\end{array}$} & $\begin{array}{c}\text { Degree of } \\
\text { substitution } \\
\end{array}$ \\
\cline { 2 - 3 } & $-\mathrm{CH}_{2} \mathrm{Cl}$ & UV absorber & $(\%)$ \\
\hline CMPSt & 32.4 & 0 & 0 \\
CMPT & 27.9 & 4.5 & 13.9 \\
CMPB & 27.3 & 5.1 & 15.7 \\
\hline
\end{tabular}




\section{3 染料の光照射}

前報 ${ }^{1)}$ 上同様に、ポリマー等のジオキサン溶液と染料 のエタノール溶液を容栍割合で 15：1 亿湿合し，染料浱 度は $1.85 \times 10^{-5} \mathrm{~mol} / /$ とした。照射距離は、全波長の 場合およびUVD2 ガラスフィルター $(290 \mathrm{~nm}<\lambda<400$ $\mathrm{nm}$ ) 使用の場合とも $20 \mathrm{~cm}$ で行なった。

\section{4 使用機器}

分光光度計は日立 200 型の紫外，可視吸収スペクトル 測定用至使用した。

光照射装置はウシオ電機製 (光源：キセノンランプ $500 \mathrm{~W})$ の染料光退色実験用を用いた。

\section{3. 結果および考察}

\section{1 紫外線吸収基含有ポリマーの吸収スペクト} ル

紫外線吸取基含有ポリマーとと机らの対照物質の HMBT, HMBP およびCMPSt の吸収スペクトルを图 1 に示した。CMPTは $344 \mathrm{~nm}$ に極大吸収波長 $\left(\lambda_{\text {max }}\right)$ を有している。この吸収はHMBTの $\lambda_{\max } 344 \mathrm{~nm}$ 上一 致している。また, CMPBの $\lambda_{\text {max }} 325 \mathrm{~nm}$ および 287 $\mathrm{nm}$ 屯 HMBP $\lambda_{\max } 325 \mathrm{~nm}$ および $287 \mathrm{~nm}$ 上一致して いる。との吸取は前報”で示した HBP 構造含むモ， マ-(BPMA) Ł St との共重合加ら合成した紫外線吸収 基含有ポリマーの $\lambda_{\max } 325 \mathrm{~nm}$ および $287 \mathrm{~nm}$ 上完全に 一致した。これらCMPT扰よびCMPBの吸収ピークは， それぞれポリマー中の側鎖の HBT 構造扰上び HBP 構 造に基づくもの上いえる。また，CMPTおよびCMPB ては低分子の紫外線吸収剂に見られない260 nm 付近上 り短波長側に著しい昍収の增大が観察され，CMPStの

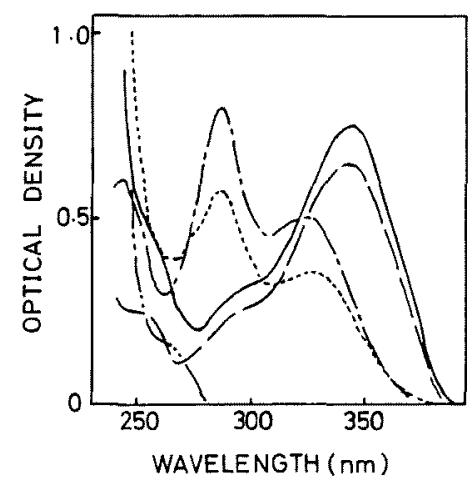

Fig. 1 Absorption spectra of ultraviolet absorbers in dioxane. - CMPT $(0.10 \mathrm{~g} / 1), \ldots-\cdots$ CMPB (0.09), - - - HMBT $2.95 \times 10^{-5}$ $\mathrm{mol} / \mathrm{l},-$ HMBP $5.60 \times 10^{-5} \mathrm{~mol} / \mathrm{l}$, - C CMPSt $0.08 \mathrm{~g} / \mathrm{l}$.
そ机とよく類似している。従って，ての吸収はCMPT およびCMPBの主鎖(CMPSt ユニット構造)に基づく おの上いえる。

\section{2 光退色スペクトル変化}

\section{2 .1 全波長に上万光照射}

全波長の照射光で行なった時のアクリジンオレンジN の光退色スペクトル恋化について述へる。图2はアクリ シンオレンジNのジオキサン一エタノ一ル溶㴼中におけ る光退色スペクトル変化である。可視吸収スペクトルは $495 \mathrm{~nm} に \lambda_{\text {max }}$ 在持占，照射時間之共に $\lambda_{\text {max }}$ はかず かにレッドシフトしなからら吸收極大の低下を示した。

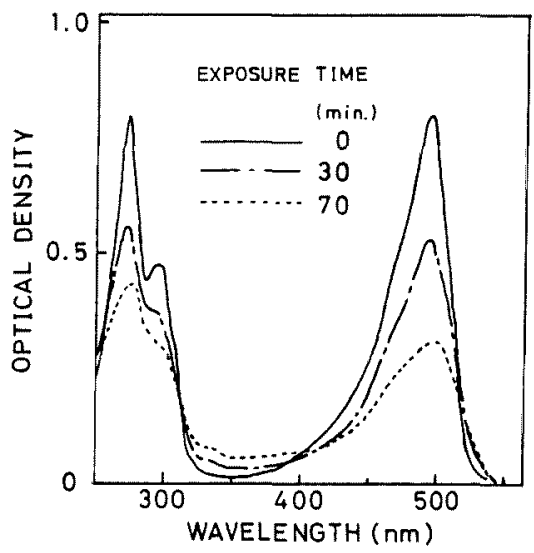

Fig. 2 Change in the absorption spectrum of Acridine Orange $N$ in dioxane-ethanol with exposure to Xenon-arc lamp. Concentration of Acridine Orange N $1.85 \times 10^{-5} \mathrm{~mol} / \mathrm{l}$.

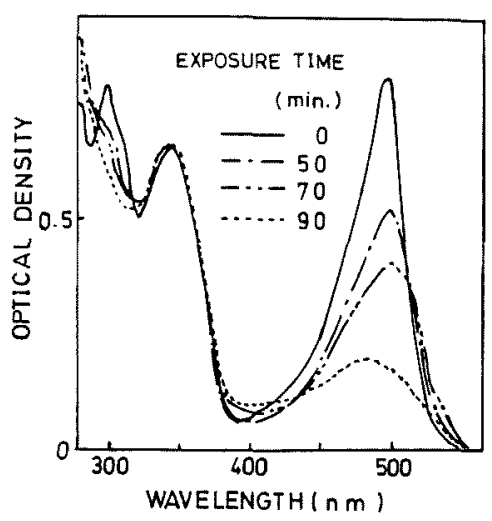

Fig. 3 Change in the absorption spectrum of Acridine Orange $\mathrm{N}$ in dioxane-ethanol solution containing CMPT with exposure to Xenon-arc lamp. Concentration of Acridine Orange $\mathrm{N}$ $1.85 \times 10^{-5} \mathrm{~mol} / \mathrm{l}$ and concentration of CMPT $0.08 \mathrm{~g} / 1$ 
HMBTあるいはHMBP染料溶液に添加した時であ， 図20然添加の時上同一傾向であった。しかしながら， 紫外線吸収基含有ポリマーを染料溶液に添加した場合に は，罒2 と異なる光退色スペクトル変化を示した。即ち、 図3に見られるようにCMPT 在添加した時の光退色又 ペクトル変化は，照射時間が70分までは $\lambda_{\text {max }} 495 \mathrm{~nm}$ をわずかにレッドシフトさせながら吸収極大の低下を示

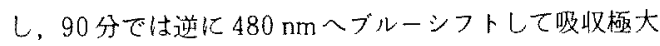
の低下示した。この様な可視吸収スペクトル変化は CMPB を添加した場合です同様に観察された。

そこで,このプルーシフトが何に起因するかについて 述べる。CMPTあるいは CMPB 中には表1に示した 上うにHBT構造あるいはHBP 構造が約 $5 \mathrm{~mol} \%$ 程度わ よび末反㣽のロメチル基が約 $27 \mathrm{~mol} \%$ 程度含まれ ている。即ち，これらポリマー鎖中には，CMPSt (32.4 $\mathrm{mol} \%$ ) 84〜86\%に相当するク口ロメチル基が残存し ている。ブルーシフトは前述したように HMBTあるい は HMBP を添加した場合でも，また，St-BPMA系 の紫外線吸収基含有ポリマーを添加した場合 ${ }^{1)}$ で観察 されなか力た。渞って、ブルーシフトはポリマー鎖中の HBT 構造あるいはHBP 構造の影忟に上るのではなく， ポリマー鎖中のCMPSt - ニット部分，即方，残存ク口 ロメチル基の影慧によって起きるととが予測される。そ こで，乙の点を明らかにするためにCMPStを添加して 光退色スペクトル変化を調べた。その結果を図4に示し た。 $\lambda_{\max } 495 \mathrm{~nm}$ は照射時間 50 分ではわずかにレッド シフトして吸取極大の低下在示し，逆に70 分では 490 $\mathrm{nm}$ に, 90 分では $470 \mathrm{~nm}$ にブルーシフトしながら吸収

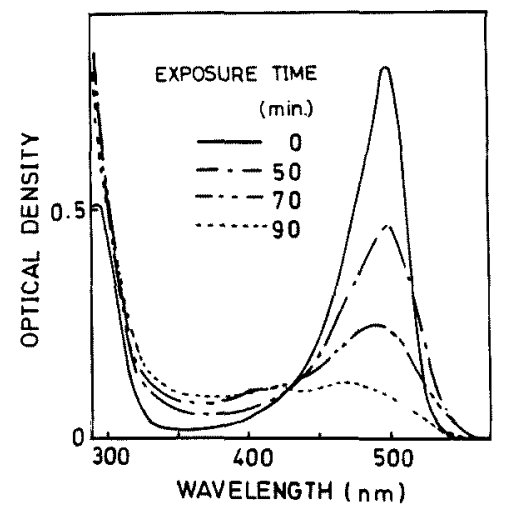

Fig. 4 Change in the absorption spectrum of Acridine Orange $\mathrm{N}$ in dioxane-ethanol solution containing CMPSt with exposure to Xenon-arc lamp. Concentration of Acridine Orange $N$ $1.85 \times 10^{-5} \mathrm{~mol} / \mathrm{l}$ and concentration of CMPSt $0.22 \mathrm{~g} / 1$.
極大の低下を示した。このように, CMPSt 老添加した 場合，予想通りブルーシフトが認められた。従って， CMPTあるいはCMPB の添加で観察されたブルーシ フトは、これらポリマー鎖中の残存クロロメチル基の影 響によって起きることが判明した。

Zimmermanら ${ }^{7)}$ の報告では， $\lambda_{\max } 279 \mathrm{~nm}\left(\varepsilon_{\max }\right.$ 1900)の3-メトキシベンジルクロリドを光恸射した絬 果, ジオキサンー水混合溶媒中では，3ーメトキシベンジ ルアルコールと3-メトキシベンジルジオキサンを，エ 夕ノールー水混合溶媒中では，3-メトキシベンジルアル コールと3ーメトキシベンジルエチルエーテルを生成す ると述心ている。即ち，光化学的な加溶媒分解生成物之 $\mathrm{HCl}$ 安生成する。彷って, 全波長照射の条件下では, 光 照射に伴い染料の光退色以外にポリマー銷中のCMPSt 土ニット部分の光化学的な加溶媒分解も起きて $\mathrm{HCl}$ を 生成し，ての HCl の染料に及ばす影響が出現したため に、ブルーシフトを伴う光退色スペクトル変化を示した おのである。そこで，その確認寒験は，门） CMPTあ るいはCMPStのジォキンーエタノール溶液を光照射 した後，ポリマーを分離除去した溶液の $\mathrm{pH}$ 測定，塩素 イオン定性㧍よでバイルシュタイン試験を行ない， HCl の存在を磼認した。椾って,これらの定性試験結果より ポリマーが光化学的加溶媒分解を起こして $\mathrm{HCl}$ を生成 するということが確認された。ｉ）染料の光退色スペク トル変化に及ぼす HCl の影響について実験した。 結果を图 5 亿示した。 $\lambda_{\max } 492 \mathrm{~nm}$ は，照射時間が 20 分では $473 \mathrm{~nm}$ に，50分では470 nmにブルーシフトし ながら吸収極大の低下を示し，50分以降はシフトせず

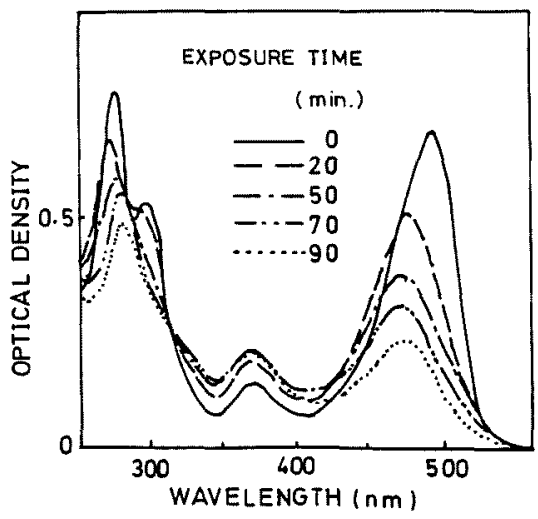

Fig. 5 Change in the absorption spectrum of Acridine Orange $\mathrm{N}$ in dioxane-ethanol solution containing $\mathrm{HCl}$ with exposure to Xenon-arc lamp. Concentration of Acridine Orange $\mathrm{N}$ $1.85 \times 10^{-5} \mathrm{~mol} / 1$ and concentration of $\mathrm{HCl}$ $0.06 \mathrm{~mol} / 1$. 


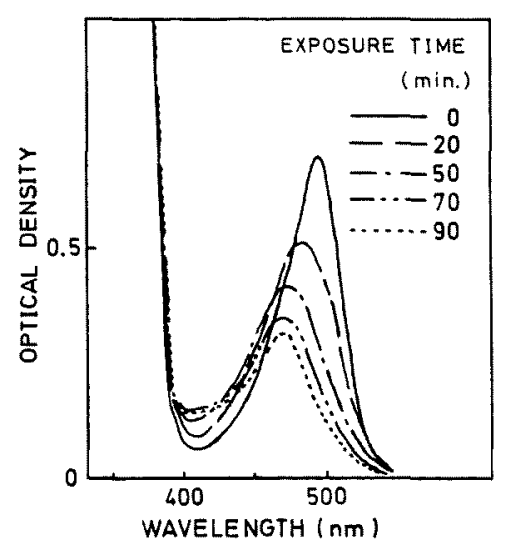

Fig. 6 Change in the absorption spectrum of Acridine Orange $\mathrm{N}$ in dioxane-ethanol solution containing $\mathrm{CMPT}$ and $\mathrm{HCl}$ with exposure to Xenon-arc lamp. Concentration of Acridine Orange $\mathrm{N} 1.85 \times 10^{-5} \mathrm{~mol} / \mathrm{l}$ and concentration of CMPT $1.0 \mathrm{~g} / \mathrm{l}$ and $\mathrm{HCl} 0.06 \mathrm{~mol} / \mathrm{l}$.

に吸収極大の低下を示した。このように塩酸を添加した 場合，照射初期において顕著なブルーシフトが認めら机 た。また，CMPT残存下で塩酸を添加した時の可視部 における染料の光退色スペクトル変化(图6)は，図 5 上 同一傾向であった。以上のとと加ら，CMPT苛るいは CMPB 添加で見られたブルーシフトは，ポリマーの光 分解化伴って遊離した $\mathrm{HCl}$ の影響である。

\subsection{2 $290 \mathrm{~nm}<\lambda<400 \mathrm{~nm}$ に上万光照射}

ポリマー銧中の残存クロロメチル基の光分解化伴う影 響在排除するために， $290 \mathrm{~nm}<\lambda<400 \mathrm{~nm}$ の照射光て 実験を行なった。染料の光退色スペクトル变化はCMPT あるいは CMPBを添加した場合です図 2 と同一傾向を 示し，全波長に上る光照射で見られた図了のようなブル ーシフトは予想通り出現しなかった。従って，との照射 光領域では，拉マー銷中の残存クロロメチル基は安定

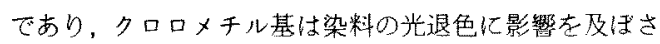
ず，ポリマー銷中の HBT 構造あるいは HBP 構造のみ に基つく効果が期待される。

\section{3 光退色曲線}

前報 ${ }^{1}$ と同棣化アクリジンオレンジNの光退色スペク トル変化を基にして光退色曲線を求如た。即ち，アクリ シンオレンジNの $\lambda_{\text {max }} 495 \mathrm{~nm}$ に拗るる照射時の光学 密度を $D_{0}$, 照射 $t$ 時間㣪の光学密度を $D_{t}$ とし，(1) 式 から染料残存率求め，照射時間に対してプロットを行 ない光退色曲線とした。但し, 塩酸添加桑の場合には, $\lambda_{\max } 492 \mathrm{~nm}$ の光学密度を基準にした。
染料残存率 $(\%)=\frac{D_{t}}{D_{0}} \times 100$

3.3.1 全波長江上万光照射

図7 亿全波長を光照射した時の光退色曲線を示した。 CMPT 添加した系では，然添加系上比較して翼なる 形の光退色曲線在示した。即方，無添加系上比較して光 退色速度は，照射特間の50 分から加速しはじめ，70

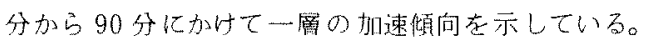
CMPB 添加系であ同傾向であった。CMPSt 添加系て は CMPT 添加系之同傾向の光退色曲線であるか，照射 時間の 50 分加ら70 分に加计て著しい加速傾向示して 退色している。塩酸添加采では，無添加柔上りも退色は 速々，特に照射初期において顕著で古る。即方，塩酸は 染料の光退色党促進することを示している。従って, CMPT 添加系执上びCMPSt添加系において，そ机之゙ れ70 分および50 尔加ら退色加著しく加速されたことは， 前述したようにポリマー銷中のクロロメチル基の光分解 に起因して生じた $\mathrm{HCl}$ の影響により，ての時点から光 退色が促進されたためである。即ち，生じた $\mathrm{HCl}$ の染 料への吸収スペクトルの影響を屯含むので, $\mathrm{HCl}$ 生成初 期においては，(1)式上り求めた染料残存涞 $(\%)$ は見持 け上小さい值を示し，加速的䬼向の光退色曲線を示した あのと考元る。

合成したCMPT等の中に Poly- O $-\mathrm{CH}_{2} \mathrm{OH}$ 型のむ のは存在しないと推定したか，念のために，この型の染 料光退色への影饗を調へるために，モデルのpーメチル ベンジルアルコールを添加して光照射実駼を行なった。 その結果, この光退色曲線は無添加系のそれと一致した。 従って，仮にPoly-

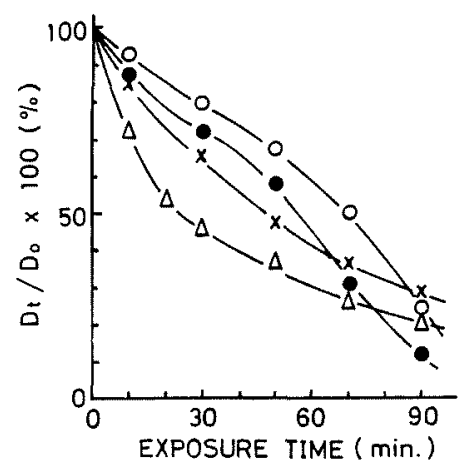

Fig. 7 Effects of additives on photofading of Acridine Orange $N$ in dioxane-ethanol with exposure to Xenon-arc lamp without glass filter (light of overall wavelengths).

$x$ without additive, OCMPT $(0.08 \mathrm{~g} / 1)$, - CMPSt $(0.22 \mathrm{~g} / \mathrm{l}), \triangle \mathrm{HCl}(0.06 \mathrm{~mol} / \mathrm{l})$. 
染料炕退色八の影觜保ないしいえる。

$3.3 .2290 \mathrm{~nm}<\lambda<400 \mathrm{~nm}$ Kよる北照射

ポリマー銷中心残存クロロメチル基の影響在受けない

$290 \mathrm{~nm}<\lambda<400 \mathrm{~nm}$ 照射光で得られた光退色曲線 一例を図8に示した。図は CMPTを添加した場合の光 退色曲線である。添加濃度 (HBTユ二ット濃度) 加增す につれて光退色は著しく逯くなり，光退色抑制效果は堌 大した。图7 し同しような光退色曲線が CMPBを添加 した場合です，また低分子の HMBTあるいはHMBP を源加した場合でも得られた。期待通り染料り光退色

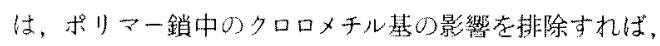

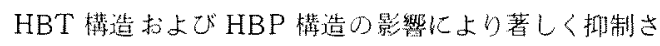
れる。

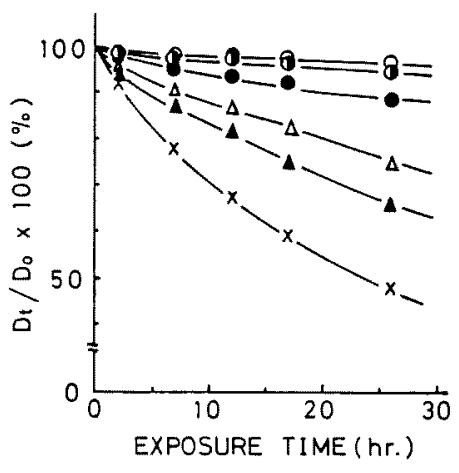

Fig. 8 Effect of CMPT on photofading of Acridine Orange $\mathrm{N}$ in dioxane-ethanol with exposure to Xenon-arc lamp using UVD2 glass filter (light of $290 \mathrm{~nm}<\lambda<400 \mathrm{~nm}$ ).

$D_{0} \quad$ Optical density of starting point of irradiation.

$D_{\mathrm{t}}$ : Optical density after irradiation for $t$ hours.

Concentration of CMPT as HBT unit ( $\mathrm{mol} / \mathrm{l}$ ):

$\times 0, \Delta 0.5 \times 10^{-4}, \triangle 1.0 \times 10^{-4} \bigcirc 3.0 \times 10^{-4}$.

$6.0 \times 10^{-4}, \bigcirc 12.0 \times 10^{-4}$

つざに，HBT 構造およびHBP 構造の光退色抑制晾 果老比較するために，得ら机た光退色曲線加ら各添加物

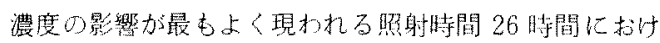
る染料残存率在表 2 に示した。HBT構造求よびHBP 構 造上屯添加物濃度の增大已其に染料残存彎の值は大きく なり，退色し嚾くなる傾向である。即ち，濃度低存性の ある光退色抑制效果を示した。CMPTとCMPBを，ま た，HMBTとHMBPを比較するよ，ポリマーおよび低

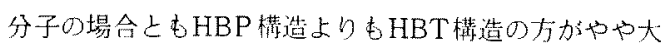
きい抑制效果を示した。また，ポマー上低方子在比较 した場合，て心抑制效果は，ポリマーのCMPT扰よ゙
Table 2 Relation between photofading of Acridine Orange $\mathrm{N}$ and additive concentration after 26 hours exposure to $290 \mathrm{~nm}<\lambda$ $<400 \mathrm{~nm}$ light.

\begin{tabular}{|c|cccccc|}
\hline \multirow{2}{*}{ Additive } & \multicolumn{5}{|c|}{$D_{26} / D_{0} \times 100$} & $(\%)$ \\
\cline { 2 - 7 } & 0 & 0.5 & 1.0 & 3.0 & 6.0 & 12.0 \\
\hline CMPT & 47.8 & 66.5 & 76.1 & 90.4 & 95.5 & 97.0 \\
CMPB & 47.8 & 63.2 & 72.0 & 84.1 & 91.6 & 93.0 \\
HMBT & 47.8 & 64.5 & 74.2 & 89.2 & 93.9 & 95.3 \\
HMBP & 47.8 & 56.2 & 63.0 & 73.1 & 81.9 & 83.6 \\
\hline
\end{tabular}

CMPBの力かそれぞれの低方子の屯の上りあ大きいて

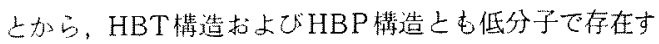
るよりもポリマー鎖中に存在する方が退色抑制に優位で

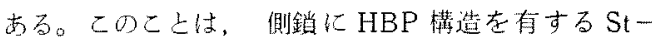
BPMA 采紫外線吸収基含有ポリマーが HMBPより6 大さな抑制効果，即ち，ポリマー効果在示すという結 果 $^{2)}$ 上一致した。

\section{4 光退色抑制効果の機構}

前報2に拁いて，HBP 構造の光退色抑制効果の原因 を明らかにするたかに，SternーVolmer プロットを試 みた。その結果, 紫外線吸収剂の添加濃度加畜くなる, 相対的星子収菜 $\left(\phi_{0} / \phi_{\mathrm{A}}\right)$ ○值は直線上に乗らずに下側 にずれた。このことから，HBP 構造は消光作用と共に 内部フィルター作用も示すか, 低濃度側では前者の寄与 か大きく、また，高濃度側では俊者の畧与が大きいと説 明した2。

ポリプロピレンツ光安定化に执いて，J. P. Guillory ら 誘導体ではフィルター作用以外に励起ポリマーの消光䇌 としての作用ああると述べており，N.S.Allen ら"は HBT誘導体扰よびHBP誘導体による三重項消光圭主張 している。また，I.H. Leaver ら ${ }^{10\rangle}$ は丰毛の光数化に おいて，HBT 誘導体加黄变防止に有効てあり，そのメ カニズムはHBT 誘導体による三重項消光によると述心 ている。

以上のこ上から，HBT惯造の染料光退色抑制効果は， HBT 構傴の消光作用に起因することが期待される。乙 の点在確加わるために、また，HBTとHBP構造の効果 を比較検討するたかに，前報 ${ }^{2}$ と同様にStern-Volmer プロットを検討した。Stern-Volmer プロットの関係式 は（2）式で表わさ机る。ここで $\phi_{0}$ 扰よび $\phi_{\mathrm{A}}$ は消光剂不 存の上きおよび消光郕を加えたよきのそれぞれの光化学 反応の量子収率とし，Qは消光剂濃度およびMば定数と する。 


$$
\frac{\phi_{0}}{\phi_{\mathrm{A}}}=1+M(Q)
$$

相刘的宣子収率 $\phi_{0} / \phi_{\mathrm{A}}$ は，已れぞれの添加桑中における

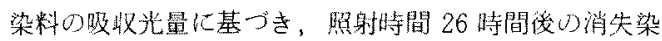

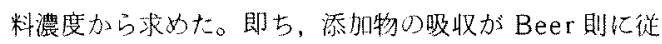
う6のと仮定し，染料之添加物 0 湿合溶液中 0 一成方 (染料) の吸取光量を笚独（染料）溶液での做を基準にし て,290nm〜400 nmo各10 nmo波長ごしに求妉 ${ }^{11}$ 。 この紫外部全体における染料の吸收光烈は，無添加時を 1 とした場合，5種の潦㨡濃度の小さい万加ら順に， HBT構造では 0.606，0.432，0.219，0.142 および0.09， HBP 構造では $0.739 ， 0.583 ， 0.349 ， 0.251$ および 0.180

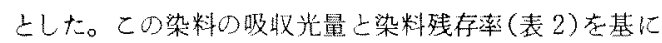
して，添扣物に上る抑制を内部フィルター作用执よび消

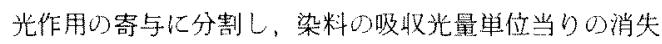
染料濃度 (\%)を求め表 3 に示した。なお，無添加時门消 失染料濃度を $100 \%$ しして示した。相対的量于取率 $\phi_{0} /$ $\phi_{\mathrm{A}}$ は, 表3在基にして（3）式 ${ }^{2,19}$ に促って求め, HBT あるいはHBPュニット濃度に対してプロットすると图 9のようになった。

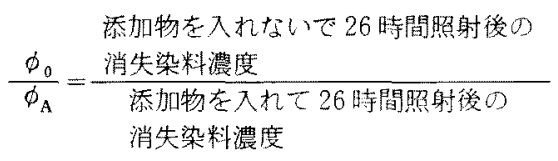

HBT 㩐造の場合，（2）式を渶足する直線関係を示して いる。また HBP 構造で向同一傾问学している。徒っ て，HBT構造はHBP檴造と同様に消光作用を示すと上

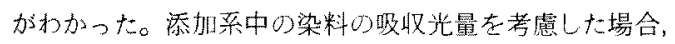
退色抑制効果は，消光作用では低濃度はど抑制される染 料量は多く，徉って，その作用の需与は低濃度側の力が 有利である。しかしながら，内部フィルター作用では当 然のととながら高濃度側乱ど，その霜与が大である考 える。

Table 3 Dye loss after 26 hours exposure to $290 \mathrm{~nm}<\lambda<400 \mathrm{~nm} \operatorname{light}{ }^{\text {a) }}$.

\begin{tabular}{|l|cccccr|}
\hline \multirow{3}{*}{ Additive } & \multicolumn{5}{|c|}{ Dye loss $(\%)$} \\
\cline { 2 - 7 } & 0 & 0.5 & 1.0 & 3.0 & 6.0 & 12.0 \\
\hline CMPT & 100 & 64.2 & 45.9 & 18.6 & 9.7 & 5.2 \\
CMPB & 100 & 70.5 & 53.7 & 30.4 & 16.2 & 9.7 \\
HMBT & 100 & 68.0 & 49.3 & 20.5 & 12.7 & 6.7 \\
HMBP & 100 & 83.9 & 71.0 & 51.6 & 34.7 & 25.0 \\
\hline
\end{tabular}

${ }^{a)}$ Dye was Acridine Orange $\mathrm{N}$ and the dye loss was calculated on the basis of the dye to be absorbed from $290 \mathrm{~nm}$ to $400 \mathrm{~nm}$ in the additive dye solutions.

The number indicated the dye loss in the no additive dye solution as $100 \%$.

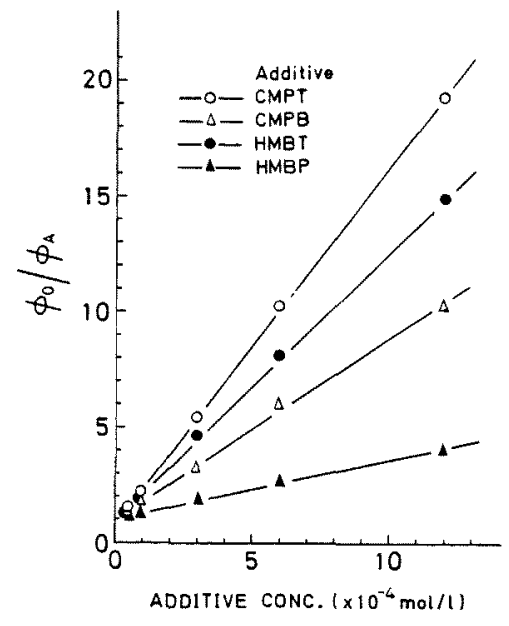

Fig. 9 Stern-Volmer plots.

アクリジンオレンジNの光退色は励起三重項状態加ら

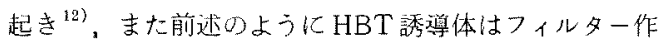
用 ${ }^{8)}$ ばかりでなく三重項の消光 ${ }^{93}$ の作用走示すとと，己 してStern-Volmer プロットの結果加ら，HBP棈造は HBP 㩐造と同様に低濃度側ではアクリジンオレンジN の恸起三重項を消光する作用が镸位であり，高濃度側で はむしろ染料の励起種の生成老抑制する内部フィルタ一 作用が侵位であるし推察される。民して，ての雨者の作 用が染料光退色抑制に奉与するといえる。染料の励起三 重項の消光については，各種の三重項消光剂添加による 確認䒠験在行ない检討する予宝である。

Stern-Volmer プロットの直線の傾きについて若干 述へる。傾きが大きいほど劯起染料分子の添加物によ り消光される割合が大れとと, 即ち, 添加物による染

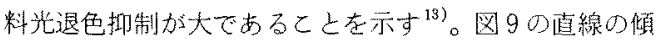
きは CMPT>HMBT>CMPB>HMBP の順に小さく

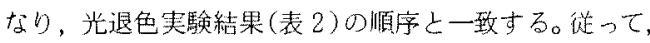
HBT 構造の方か HBP 構造上りあ消光の效率がよいため 亿前者の万が優位な抑制効果を示したものと考えられ る。しかし，前者の与加何故消光の效率肪上小加にいい ては㒻在の所，明らかではない。また，HBT 構造およ びHBP 構造とも低分子よりもポリマ一の方方消光の效 率加上600で, 優位な抑制効果, 即ち, ポ少、一効果老 示したもの上考无战る。この消光の効率は，低多子よ りむむしろポリマ一の方加染料上相互作用しやすいため 有利になると推祭される ${ }^{(4)}$ 。この点に関しては，紫外線 吸収基含有ポリマーの染色等の別の角度加的更に检討在 加え報告する。 


\section{4. ま め}

(1) CMPSt とDHBTあるいはDHBP との反尤によ りポリー銷中に紫外線吸収基(HBT 権造あるいはHBP

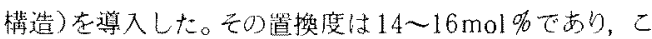
れら紫外絁吸収基含有ポリマー(CMPTおよびCMPB) 中には CMPSt の約 $85 \mathrm{~mol}$ \%程度に相当するクロロメ チル基殘存した。

（2）アクリジオレンジNの光退色的拀て，全波長 による光照射の場合に洨，CMPTおよひCMPBの光退

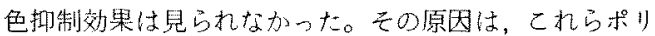
マー鎖中心残存クロロメチル基の光分解に起因して生ず 万 $\mathrm{HCl}$ の光退色促進効果が出現したためである。しか し, 残存夕口ロメチ儿基の光分解在引き起しさない290 $\mathrm{nm}$ 以上の光照射の場合には，CMPTおよびCMPB上 6光运色抑制効果老示した。

（3）紫外線吸収剂の光逐色抑制効果は， $\mathrm{HMBP}<$ CMPB<HMBT< CMPTの湎に大であった。

(4) HBT構造はHBP構造上闰様に，消光作用および

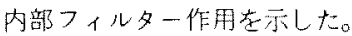

付 記：本研究心一部は, 昭和56 年6月23日，第 23 回染色化学詩諭会(東京)で発表した。
文献

1)鈴术洋正，由中祥惠，石井美治，繊学誌，39， $\mathrm{T}-118(1983)$

2) 鈴术洋正，石井美治，山下雄也，繊学誌，41， $T-131(1985)$

3) J. VanAllen, J. F. Tinker, J. Org. Chem., 19, 1243 (1954)

4) M. Karvas, J. Holoick, Chem. Prum., 17, 543 (1967)

5）星野解雄，你出直也，「高分子合成奏験法」，東 京化学同人，p.145(1967)

6) G. D. Jones, Ind. Eng. Chem., 44, 2686 (1952)

7) H.E. Zimmerman, V.S. Sandel, J. Am. Chem. Soc., 85, 915 (1963)

8) J. P. Guillory, C. F. Cook, J. Polym. Sci., 11, 1927 (1973)

9) N. S. Allen, J. Homer, J. F. McKellar, Makromol. Chem., 179, 1575 (1978)

10) H. Leaver, J.P. Waters, N. A. Evans, J. Polym. Sci., Polym. Chem. Ed. 17, 153 (1979)

11）山田仁穂，正泉寺秀人，内田光則，五十風博, 日化, 1974, 566

12) F. Millich, G. Oster, J. Am. Chem. Soc, 81, 1357 (1959)

13）根来健二，西原邦夫，日化， 1978，602

14）鉿木洋正，佐藤 誠，佐藤伸次，时中祥惠，石井 美治，第 26 回染色化学討論会プログラム，p.77 (1984) 